\title{
The Penguin Revolution in Chile: Exploring Intergenerational Learning in Social Movements
}

\author{
Donna M. Chovanec \\ donna.chovanec@ualberta.ca \\ Alexandra Benitez \\ benitez.alexandr@hotmail.com
}

University of Alberta

\begin{abstract}
In this paper, we introduce the Penguin Revolution, a social movement of high school students in Chile who are protesting the neo-liberalization of education in their country. This new activism surprised many because of the marked decline in political mobilization witnessed over the past 18 years since the Pinochet dictatorship. Findings from an earlier study of the women's movement in Arica, Chile bear important clues to understanding the re-emergence of social action in the current generation, particularly the role of intergenerational learning (Chovanec, 2006a, 2006b). First, previous generations of women had developed a strong critical social consciousness that did not disappear during the years of retreat from direct political engagement. Second, although social movements may be quiescent, there are mechanisms for quiet continuity that engage all three generations of women in the community. We argue for providing a deliberate political education to the younger generations by drawing on the radical educational potential of parents as organic intellectuals and the historical promise of political parties as political educators.
\end{abstract}

\section{Introduction}

Penguins are on the march in Chile! Named for the colour of their school uniforms, the Penguins are Chilean high school students fed up with the neo-liberalization of public education in their country. Between April and August 2006, over a million students mobilized in strikes and school takeovers across the country, demanding that the government ensure equal access to a quality education for all (Vogler, 2006). They lobbied for free bus fare, waiving the university admissions test fee, reform to the fulltime school day policy, and abolition of the law to privatize the education system. Disgruntled with the slow pace of action on their issues and unsatisfied with the proposed changes to educational legislation, they renewed their protest the following year in April 2007.

Not since the massive mobilizations in 1983 to 1989 , during the final years of the military dictatorship in Chile, has there been an uprising of this magnitude. Nor has there been, during the 18 years of the elected government of the centre-left coalition, any direct assault on the legacy or the legitimacy of the neo-liberal socio-economic order left in the wake of the dictatorship. In this paper, we consider how and why this new generation has

Journal of Contemporary Issues in Education, 2008, 3(1), pp. 39-57. ISSN 1718-4770 @ 2008 University of Alberta http://ejournals.library.ualberta.ca/index.php/JCIE 
not only developed an astute critical analysis of the political and economic situation in Chile but has also taken bold and decisive oppositional action.

This paper emerges from our interest in and study of the women's movement in Chile. In 2001-2002, Chovanec did nine months of ethnographic fieldwork in Arica, a small city in northern Chile, with the primary objective of exploring the phenomenon of social and political learning in social movements (Chovanec, 2006a, 2006b). ${ }^{1}$ Findings from that study led her to initiate an analysis of intergenerational learning that was further stimulated when the Revolución Pingüina (Penguin Revolution) emerged in 2006.

Although we do not specifically address feminism in this paper, our questions echo those posed in the emerging scholarship on the feminist "third wave" and its relationships to and conflicts with earlier waves of feminism (Baumgardner \& Richards, 2000; Purvis, 2004), particularly the lack of specific attention in the literature to "the possibilities for, and difficulties with, passing on feminism from generation to generation" (Hoogland, de Vries, \& van der Tuin, 2004, p. 261). In our current research, we are combining information on this emerging activism in Chile with previous research findings from the Chilean women's movement to explore intergenerational learning in social movements.

Following an historical sketch of the socio-political situation in Chile, we present a short chronology of the student movement. We then turn our attention to the mothers and grandmothers of this generation of students to begin a provisional analysis of the role of intergenerational learning in the current student movement, with a particular focus on the development of critical social consciousness and the role of local mechanisms for social movement continuity. Derived from this analysis, we argue for the importance of incorporating a deliberate educational dimension into social movement activism, particularly emphasizing the radical pedagogical potential of parenting education and recognizing the historical promise of political parties as institutions of radical adult education. Finally, we suggest directions for future research.

\section{Repression, Resistance and Transition in Chile}

Any social movement is situated within a particular nexus of time, place and history. In this section, we briefly recount some key historical moments from the recent past to outline the socio-political context within which the current student movement has emerged.

\section{The Repression}

Unlike many of its Latin American neighbours, Chile had a long social democratic tradition that resulted in the election of a socialist president, Salvador Allende, in 1970. However, the socialist experiment that included nationalization of industry (especially in natural resources) and land reform, proved too threatening for both national and

\footnotetext{
${ }^{1}$ Methods included cultural immersion, document review, participant observation, and interviews. In total, Chovanec formally interviewed, individually or in small groups, sixty women active in social/political movements in Arica at some time during the previous thirty years. The participants ranged in age between 25 and 78, covering two generations of women.
} 
international powers. Aided by internal agitation from the upper classes and the involvement of the United States (see for example, Chavkin, 1985), a military coup d'etat overthrew the Allende government and installed a military dictatorship under the direction of General Augusto Pinochet in 1973. Immediately thereafter, the constitution was suspended, media was censured, and political parties and trade unions were prohibited. During the bloody early days of the coup, thousands were captured, detained, tortured, disappeared, and/or executed. Almost 3000 people were assassinated by the Chilean state during the dictatorship years, 1000 of whom have not been found. Political leaders, community organizers, labour activists, and intellectuals who escaped this fate were forced into hiding while the rest of the citizenry was paralyzed by fear. ${ }^{2}$

The repression of the citizenry established the climate needed to experiment with economic restructuring without worrying about the destabilizing tendency of popular political activity (Craske, 1998). Based solidly in the emerging neo-liberal economic model, the Chilean military regime applied international guidelines for a market economy within the first years of the coup (Chavkin, 1985; Silva, 1991) and then, in the 1980s, instituted externally imposed Structural Adjustment Programs (SAPs). As a result of the reduction and privatization of government services mandated by these programs (among other requirements), there was a 27 percent reduction in the public budget in Chile (Schuurman, 1993) creating extreme poverty in already impoverished communities around the country.

\section{The Resistance}

Although the history of oppression is strong, so too is that of resistance and dissent. The region has a vibrant history of trade unionism and women's, workers', peasants', and indigenous people's movements. Although these movements were immobilized and then

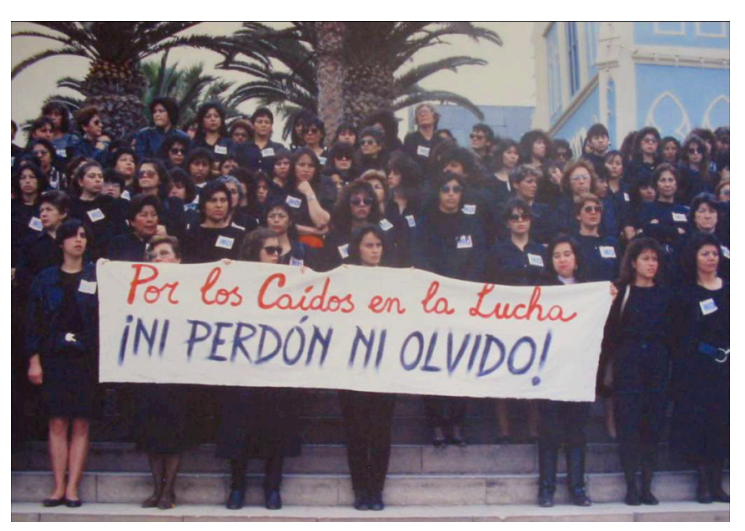

Women protesting in Arica, Chile during dictatorship

"For those who have fallen in the struggle, we will neither pardon nor forget!" operated underground during the first years after the coup, "during the early 1980s, social movements reemerged and formed the backbone of the popular protest movement" (Hipsher, 1996, p. 280-281). The years 1980 to 1989 witnessed various collective responses to the economic and human rights abuses, including the outbreak of organized mass protests across all sectors of society. The first National Day of Protest occurred on May 11, 1983 followed by the first mass mobilization of the women's movement against the dictatorship on August 11, 1983.

In the same year, women in Arica

${ }^{2}$ The Agrupación de Familiares de Detenidos Desaparacidos de Chile published the statistics in this paragraph. [http://www.afdd.cl/]. They are drawn from the government reports produced by the National Truth and Reconciliation Commission (Rettig Report) and the National Corporation for Reconciliation and Reparation. Similar statistics were published in the Washington Post ("Pinochet's Chile", 2000). 
mobilized through two women's organizations, CEDEMU and MODEMU. ${ }^{3}$ Despite their divergent philosophical stances on feminism and the goals of the women's movement in Arica, the women in these groups were united in the common objective of ousting the dictatorship. ${ }^{4}$ The activities in these groups ranged from open demonstrations to clandestine activities, and from practical support to feminist consciousness-raising. Together, they organized special demonstrations and cultural events around major dates, such as the anniversary of the coup and International Women's Day. Women also demonstrated leadership and significant participation in other social/political activities in Arica. These included communal survival-oriented activities, such as collective kitchens, and human rights organizations. A powerful human rights group was El Movimiento Contra la Tortura Sebastián Acevedo whose members took a public, brave and nonviolent approach to denouncing the abuses of the dictatorship. In Arica, many women were inducted into leftist political parties/movements through clandestine cells in schools, the university, workplaces, and neighbourhoods. ${ }^{5}$ Younger activists used music, dance, theatre, poetry and visual art to publicly denounce the dictatorship, condemn injustice, and bolster solidarity. The Roman Catholic Church parishes that actively practiced liberation theology made a distinctive contribution to the social movements in Arica by providing a safe place for clandestine meetings and a sanctuary for the pursued and persecuted.

\section{The Transition}

While most Latin American dictatorships dissolved for various reasons during the early 1980s, the Chilean military government outlasted all others. When a plebiscite dictated by Pinochet's own 1980 constitution was called in 1988, a broad-based coalition of antidictatorship groups successfully waged a campaign to vote against continued military rule. This obliged Pinochet to hold elections in 1989 after seventeen years as dictator. A coalition of center-left parties, the Concertación por la Democracia, initially negotiated the terms of transfer to civil rule and has been successful in each of the four subsequent elections. The terms of the transition included various concessions that would ensure the entrenchment of neo-liberalism and the appeasement of social movements. Thus, in order to secure a stable transition to democracy, social justice demands were put on hold. "Responsible citizens put the needs of the nation (that is, the economy) before personal demands (that is, social justice)" (Craske, 1998, p. 110).

In the early days of the transition, the new government was hampered by a combination of anxiety about the potential for a renewed military takeover and the negotiated terms of the transition. However, after 18 years in government, it seems clear that the Concertación lacks the political will to confront the human rights abuses of the

${ }^{3}$ CEDEMU is Centro de Estudio de Mujer (Women's Study Centre) and MODEMU is Movimiento de Mujeres (Women's Movement).

4 We refer to the women's combined activism during the anti-dictatorship struggle somewhat euphemistically as the "women's movement" specifically because the diverse expressions of activism and their contested relationships to feminism are much more complex than can be addressed in this paper and are not the intended focus of the paper. See Chovanec (2004) for a detailed discussion of this dynamic.

5 While some women joined the Socialist Party or the more radical, Movimiento de Izquierda Revolucionaria (MIR), the vast majority of women active in social movements in Arica were militants in the Communist Party and the Young Communists. 
past, to overcome growing economic inequality or to consolidate a vibrant democracy in Chile. ${ }^{6}$ Faced with the current neoliberal "pseudo-democracy," Arica women's movement are generally cynical and apathetic. They do not feel well represented or served by the official women's ministry, SERNAM, which initially grew out of the strength of their movement, nor has any semblance of the vitality of the earlier grassroots movements yet re-emerged.

\section{Neo-liberalizing Education in Chile}

For today's youth, a distressing example of the neo-liberal legacy left by the dictatorship is the LOCE - the Ley Orgánica Constitucional de Eseñanza (Organic Constitutional Education Law) - introduced just one day before Pinochet surrendered power in March 1990. The consequences of the LOCE have been profound and significant to education in Chile. Under this law, "the state drastically reduced its role in the educational sector." The new system was "based on free markets, private management and profit-oriented education" (Alarcón Ferrari, 2007, p. 6). Educational administration was decentralized and devolved to municipal governments while the Ministry of Education retained control of curriculum development and design, student performance and assessment (Matear, 2007).

Three categories of schools resulted from this new system of education: private, subsidized private (funding from the state and from parental fees), and municipal schools. Municipalities were given control of public schools, including decision-making and management of public education services. Differences between rich and poor municipalities resulted in differences in the quality of education offered to students, since those with more money could afford to invest more. Declining government spending and reduced commitment to public education led to a clear decrease in the quality of public education which, in turn, encouraged a growing number of parents to enrol their children in private or subsidized private schools. According to statistics from the Ministry of Education, in 1981, 78 percent of students were educated through the public system, 15.1 percent through subsidized private schools, and 6.9 percent were enrolled in private schools. By 2004, the numbers had changed significantly with only 49.4 percent in public schools, 41.5 percent in subsidized private, and 7.7 percent in private schools (Bloque Social, 2006). Under LOCE, then, the right to education signifies protecting a free market education (Alarcón Ferrari, 2007). Rather than ensuring equal access to quality education, quality education is reserved for those who can afford it $(\mathrm{OPECH}, 2006)$. Yet, there are very few measures to monitor the quality or the spending of private schools.

Other effects of the LOCE include lower achievement levels at the secondary school level and inadequate university preparation (Matear, 2007). The LOCE has also served to deepen social inequalities based on the social origin of students (Alarcón Ferrari, 2007). For example, private schools have the right to select their students in any manner they see fit, thus allowing schools to segregate or discriminate against poorer students who do not have the opportunity to attend better schools. Selective enrolment also gives private schools better results in national testing.

\footnotetext{
${ }^{6}$ See Bresnahan (2003) and the rest of the authors in this special edition for a discussion of the negative effects of neo-liberal economics on the democratization process in Chile.

${ }^{7}$ Throughout the paper, quotations are from research participants unless otherwise specified.
} 
Despite growing discontent and deepening distrust of public education, the elected government did not reform or repeal the LOCE in over 18 years. The law was difficult to change because such changes require a parliamentary majority, almost impossible to achieve with the current binominal electoral system (another legacy of the dictatorship that ensures continuing right wing advantage). As a result, the Concertación government attempted minor modifications to LOCE and to the educational system (Gamboa \& Pincheira, 2006) but problems with "over-crowding, large class sizes and improving the quality of teaching remained" (Matear, 2007, p. 105). Matear points to the contradiction between government policies to promote equity and social mobility, on the one hand, and the legislative framework that perpetuates a market-based educational system rooted in competition and an inequitable distribution of educational opportunity, on the other. She further argues that the military regime introduced LOCE as an astute means to continue the transmission of neoliberal ideology and values, now deeply rooted within the education system itself. Against this socio-political backdrop emerged the student movement in 2006.

\section{The Penguin Revolution}

The Penguin Revolution started on April 24, 2006, organized by the Coordinating Assembly of High School Students (ACES), a group formed through the merger of political youth organizations. It began as a reaction against school bus fares and university entrance fees. From there, it grew into a national movement demanding quality education for all. The movement was fuelled further when President Michelle Bachelet failed to address educational reform in the annual presidential speech

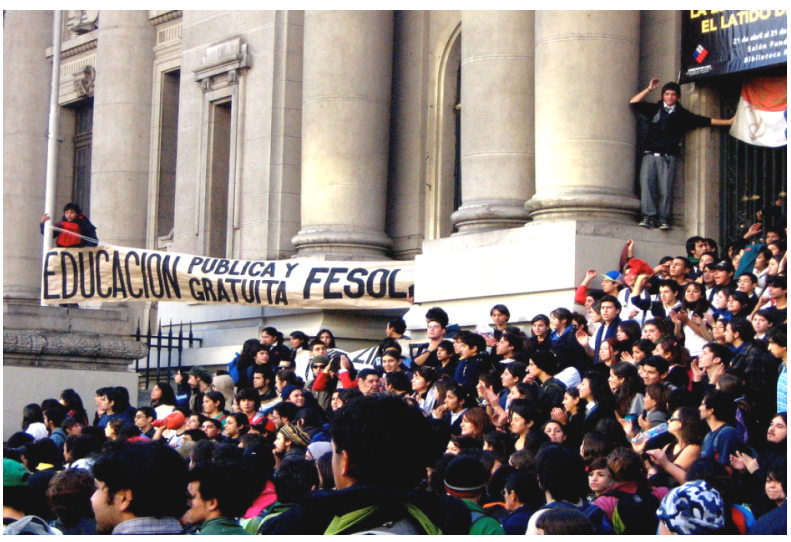

Students protesting in Chile 2006 on May 21, 2006. Student leaders responded by calling for continued demonstrations and school takeovers. Support for public school students grew as the movement attracted the participation of university students, teachers, parents, and eventually from private school students. More schools were taken over around the country until up to 100,000 students were involved in mass demonstrations (Internationalist Striker, 2006, p. 18). Facing increasing pressure, Minister of Education, Martín Zilic, called a new round of negotiations for May $29^{\text {th }}$, but he antagonized the students first by sending his deputy minister and second by providing space for only a few students. As a result, ACES called the first national strike for May 30th and quickly got the word out through cell phones, blogs and chat rooms (Vogler, 2006).

Demonstrating secondary students, along with many university students, totalled between 600,000 to one million (Internationalist Striker, 2006, p. 22) and effectively immobilized almost all of Chile's schools and universities (Vogler, 2006). Despite these being peaceful protests, police exerted excessive force across the country by beating, tear-gassing, and soaking students with water cannons. The police brutality outraged the 
general public and led President Bachelet to immediately fire the head of Chile's riot police and soon afterward, Minister Zilic. The growing public support pressured the president to become directly involved in negotiations with the student leaders and, on June 1st, she made her first public offer, in which she met some of the students' minor demands, offered unspecified changes to the LOCE and proposed a presidential advisory council for education (Díaz Miranda, 2006). ACES rejected the president's offer because it did not include free bus fare and because they were not satisfied with the number of student representatives to be included in the new advisory council.

Although the movement was now beginning to show signs of internal disagreement between radical and moderate groups within ACES, the students continued demonstrations and school occupations and the leaders called another national strike for June 5th. The government then announced several new measures that met more of the students' demands, prompting the students to return to classes. June $12^{\text {th }}$ officially marked the end of the strike. However, according to Maria Jesús Sanhueza, one of the more radical leaders of ACES, "This isn't the end of our movement, just a change in the way our demands are articulated. We go back incredibly happy with what we have achieved. We know full well that our victory is historic and hard earned" (Vogler, 2006).

As she anticipated, demonstrations and takeovers continued across the country from August to the end of the school term in November, albeit with fewer students. Following the arrest of 40 students at a school takeover, student leaders called another national strike for October 19th. Several thousand students participated in the strikes in Santiago and across Chile, during which over 350 students were arrested (Setterfield, 2006, I 1). Student demands remained the same, however, the national government seemed less responsive to student demands and students faced sanctions at the school level. For example, they were prohibited from organizing meetings during school recess and an increasing number of students were expelled, given conditional registration, encouraged to attend other schools, and/or only permitted on school grounds when taking exams (Chávez, 2006).

Nevertheless, the students resumed demonstrations in March 2007 upon their return to classes after the summer holidays. A large demonstration was held on March 29th, a day of protest marking the anniversary of the 1985 killing of two students by police during an anti-dictatorship demonstration. Just prior to the winter break on June 6th, students from some of Santiago's most prestigious schools initiated school takeovers. From then, the protests became aligned with broad-based movements challenging neoliberalism across all sectors (e.g., education, pension, housing). "Hundreds of unions have joined, including the National College of Physicians, the Teachers Union, and the Students Unions of most major universities in the country as well as the Secondary School Association, the ones that have been at the centre of the activities against the government" (H. González, personal communication, Aug. 29, 2007).

The student protest now included concerns about public transportation and young offenders legislation, as well as dissatisfaction with the slow pace of promised educational reform. The latter, despite notable success in prompting the president to move on new legislation to replace the LOCE, the Ley General de Educación, which she initiated on April 6, 2007. As predicted by Vogler (2006), "the student movement placed education at the top of the political agenda and paved the way for reform of the ... LOCE" ( $\mid 20)$. The new legislation tackles three thorny issues raised by the students: it 
abolishes the public financing of profit-making educational institutions, prohibits the practice of student selection in publicly funded primary and middle schools, and establishes a multi-sectoral national education advisory council. However, critics complain that these reforms fail to address the disastrous fallout from the LOCE, particularly a now entrenched system of inequality based on socio-economic means (CENDA, 2007). Ultimately, the legislation "is insufficient if there is no reform to the Political Constitution and if it doesn't define a more active role for the state as the provider of public education nor guarantee the right to a quality education for all Chileans" (OPECH, 2007, I 5). According to protestors, "there are more than enough reasons for us to begin protests again" (Pavez quoted in Setterfield, 2007, ๆ 14). Young activists interviewed in September 2007 concur. "Our proposal is for free and public state education.... This year again we will continue with marches. We are going to continue with our proposal until the end, ... until we succeed." ${ }^{\circ}$ As of November 2007, the new law had not yet been approved by parliament although both the government and the opposition parties have signed an agreement to move it forward (Roberts, 2007).

\section{Intergenerational Learning}

Through media coverage, electronic literature and our contacts in Chile, we have noted that young women are playing an integral role in the leadership and public presence of the student movement. This generation of students, typically born in the final years of the dictatorship or shortly thereafter, are the daughters and granddaughters of the women's movement participants interviewed in 2002. While we are not yet sure of the specific nature or the significance of the gender composition of the student movement, the recent eruption of activism within this generation of women is an exciting development that begs interesting questions about intergenerational learning in social movements. By juxtaposing experiences from the earlier generations of the women's movement in Arica alongside the current generation of women in the student movement, we can begin to ask questions about the processes of learning that sustain activism across generations. For example, what is the relationship between the politically active older women, the social consciousness of the younger women, and the robust activism of the youngest women? How can learning across generations be facilitated and enhanced in order to mobilize and revitalize women's social movement participation in the next generation?

Similar to earlier analyses (see for example, Alvarez, 1999; Franceschet, 2001; Schild, 1998), Chovanec's research documents multiple reasons for the depoliticization and demobilization of the women's movement in the post-dictatorship, neo-liberal period in Chile. However, a distinctive factor that emerged in her analysis was the differential impact of activism on three generations of women. In the first, or eldest, generation were women over 45 years of age (when interviewed in 2002) who were married adults with children at the time of the coup and in mid-life during the anti-dictatorship struggle. The second, or younger, generation represented women 20 to 45 years of age when

${ }^{8}$ Our research associate in Chile, Héctor M. González, conducted and transcribed an exploratory interview with two student leaders in Arica, Chile (September 1, 2007) from which this quote is an excerpt. The interview is part of an ongoing research project on social and political learning in the women's movement in Chile. 
interviewed, who were very young or born during the dictatorship and were most politically active during their adolescence. The third, or youngest, generation is comprised of the students who are now mobilizing; they were typically born in the final years of, or after, the dictatorship. During the 2002 research project, interviewees from the generations of their mothers and grandmothers talked about these younger girls/women but the members of this youngest generation were not interviewed directly.

The first generation of women demonstrated an astute political sensibility credited to their families, communities, political parties and community organizing. They had belonged to political parties for many years and had been politically educated by the party prior to the coup. Mobilizing out of a sense of "necessity" later in the dictatorship, they rekindled previous political networks and negotiated new ones across party lines. These women were responsible for initiating all of the major public responses to the military regime in Arica. Disillusioned by the eventual outcome, they became more wary of formal politics during the transition, but they remained strongly grounded in their political ideologies. After 1990, they generally returned to the spaces and pace of their earlier lives albeit with new understandings, strengths and convictions. ${ }^{9}$ One woman reflected: "The dictatorship did us a favour in that sense because it liberated us. I, for one, was stuck in the house all my life. So women became more independent... and learned to value [themselves] more." But, "afterwards, each one returned to her home."

In contrast, the second generation of women were jettisoned into social movement participation in adolescence and lived their formative years at the intersection of the repression of the dictatorship and the resistance of the social movements. This contradiction led to profound consequences in their social, political, interpersonal and personal lives. In addition to having difficulties in long term relationships and career repercussions from educational gaps, these younger women complained bitterly about lacking the "ideological education" that they had expected to obtain through their political participation. Although some were taught by the example of their parents, these younger women did not have the benefit of the political education enjoyed by their elders in a more politically open environment prior to the dictatorship. Instead, the idealism and energy of their youth was channeled into action on barricades in their neighbourhood streets or strikes on campus, without a solid ideological grounding. Many of these younger women felt used, manipulated, betrayed and cheated out of an educational opportunity. One woman who was an anti-dictatorship activist in her youth explained:

It was the time to fight and go out into the streets but there was no ideological preparation ... We students worked in accordance with our necessities ... There was no solidness, ideological solidness. It was like they threw us to the mouth of the lions ... For me, the Pioneros [political group for younger students] was a time to prepare oneself to participate in the larger movement and I felt that it wasn't. I mean, for me, it was like that. And the people that were there, that had to prepare me, didn't.

\footnotetext{
${ }^{9}$ Although, some of the women were deeply effected by the introduction of feminism into their lives and their activism (see Chovanec, 2004), this is not addressed in this paper.
} 
Thus, the lack of attention to the transfer of learning between generations contributed to disillusionment and political inactivity in this second generation of women. In the absence of the kind of political socialization that was experienced by the first generation, these younger women were unable to coalesce around new objectives that are required to sustain the movement in a new era. Subsequently, these women were neither politically active nor involved in movements. ${ }^{10}$

But what about today's youth, the third generation, who are labeled by politically and socially minded Chileans as "no están ni ahi" ("they aren't anywhere")? Some of these are the girls that played innocently "under the tables" as their mothers and grandmothers clandestinely planned and protested. Others were born amidst the disillusionment and despair of the early transition years after the dictatorship, a period of social movement decline. This generation was raised by a generation of adults/parents who were themselves raised amidst the repression and resistance of the dictatorship years. Under conditions reminiscent of the devastating cultural effect on parenting in Canada's First Nations communities after the residential school years, one wonders, what is the societal effect on parenting and childrearing after the dictatorship in Chile? What effect does a system based on fear and suspicion have on trust and communication at micro and macro levels in subsequent generations? Has violence, fear, skepticism and disillusionment been imprinted on these youth?

Despite such a legacy, this third generation - the Penguins - has stepped forward onto the activist stage.

The students who organized the walkout, represent the first modern generation of political actors who did not grow up under the military junta. They are children of a rather anemic democracy whose closest connection to the dictator are the neoliberal social and economic policies, against which they now are openly fighting. (Hatfield, 2006, ๆ 6)

Through the ideologically informed mobilization of their grandmothers and the bold activism of their mothers, women in the third generation are descendents of the antidictatorship struggle. But they are also witnesses to their elders' disillusionment, despair and political immobility in the aftermath of the dictatorship years.

The stark difference in the political characteristics between their and their parents' generations is evident in the nature of the student protest. Rather than shying away from the collective action and political participation as their parents had, Chilean students have shown not only a willingness to organize and express themselves, but also a special affinity for it. (Hatfield, 2006, \7)

How do we make sense of this new activism, especially in the absence of a solid political formation and mentoring? What effect has the social activism of the previous generations had on this third generation? Might solidarity, social consciousness, and political

${ }^{10}$ Various aspects of these findings are echoed in other studies of participation in social movements (Klandermans, 1997; Marwell, Demerath III, \& Aiken, 1993; McAdam, 1989; Moyano, 1992; Olavarría, 2003; Van Dyke, McAdam, \& Wilhelm, 2000). 
commitment also be imprinted upon these youth? In the remainder of this paper, we consider two themes from the earlier research (Chovanec, 2006a, 2006b) - critical social consciousness and social movement continuity - that provide a partial response to the questions about intergenerational learning raised in this paper.

\section{Critical Social Consciousness}

Evidently, the Penguins developed some sort of critical consciousness about issues of educational equality and quality that prompted them to act. Thus, a potentially fruitful analytical avenue to exploring the mobilization of the Penguins is through an analysis of the development of critical social consciousness in the two earlier generations of women.

According to Gramsci (1971), "The child's consciousness is not something 'individual' (still less individuated), it reflects the sector of civil society in which the child participates, and the social relations which are formed within his [sic] family, his neighbourhood, his village, etc." (p. 35). Many studies of social activists reveal the impact of early political socialization (see for example, della Porta, 1992; Marx \& McAdam, 1994). Based on her studies of left wing underground organizations, della Porta (1992) reports that, "young activists often reflected a continuity with the political traditions of their families" (p. 7). Thus, we speculate that acquiring such a consciousness organically occurs during the early years as we learn values and beliefs from the collective that makes up our social world.

In Arica, women anti-dictatorship activists had "participated in a family dynamic where the political was part of the conversations ... Under those conditions, it wasn't strange that a particular worldview would be shaped in childhood" (Cortez Díaz \& Villagra Parra, 1999, p. 118). Most women in Chovanec's research were rooted in families and communities that espoused leftist philosophies through participation in political parties and/or exposure to liberation theology. They were cognizant of the legacy of earlier workers' and women's struggles and the political trajectory that ultimately led, in 1973, to an elected socialist government in Chile. But, even for those women whose social environment was not explicitly leftist, seeds were sown in their early learning of values related to fairness, dignity, and community. This early learning established a set of communitarian values, humanist/socialist philosophies, and/or marxist ideologies that provided the foundation upon which the women developed their critical social consciousness, often at very young age.

Ideas or thoughts can "become part of our consciousness when we receive them from an external source ... [but] reception depends upon our active engagement with them" (Allman, 2001, p. 165-166). In Spanish, it is more common to use the word "tomar" (to take) when referring to consciousness (Chovanec, 2006b). The idea of 'taking' critical consciousness implies an intentional commitment made by women whose own lived experiences resonate with their already acquired consciousness. As they entered their youth, many women in Chovanec's study made deliberate choices to act upon their consciousness. Thus, women became party militants themselves or they affiliated themselves with party militants. Some actively participated in the local Catholic parishes that professed a theology of liberation. Prior to the coup, the older women had worked for Allende's campaigns, participated in community organizations, and established their homes through land takeovers. So that, in living out their "potential 
consciousness," it was deepened and expanded into a "real consciousness" (Freire, 1990/1973, p. 105).

The two generations of women preceding the Penguins had experienced the "active engagement" of which Allman (2001) speaks. Thus, the consciousness acquired in childhood had later become internalized and subjectified-it was taken into oneself. It did not disappear, even in the absence of an ideological education that would have provided theoretical grounding for the how and why of this consciousness, or in the skeptical and distant approach to politics after the dictatorship and during the transition period. Everyone in Chile talks politics - even when they profess to be "apolitical." What would conversations around the dinner table in the homes of these women be like today-these women sitting down to dinner with their adolescent daughters and granddaughters? How is the political consciousness of mothers manifest in daily life, even as their daughters don their black and white uniforms and head out the door to that most political of social institutions - the school?

\section{Social Movement Continuity}

Another avenue for exploring the Penguins' mobilization is to analyze the mechanisms by which the women's critical social consciousness might be expressed in the present day. Are there processes and forms through which their earlier social activism is maintained or continued?

Recent social movement scholarship refutes the "immaculate conception" view of social movements which assumes that new "waves" of activism emerge spontaneously and are largely unconnected to previous waves and movements. Of particular note are findings from the women's movement in the United States suggesting that movements "persist" (Whittier, 1995) in generally inhospitable political climates through "abeyance structures" (Taylor, 1989) that keep the movement in a holding process between active stages of the movement. "Through the combination of longtime and incoming feminists, the [U.S. women's] movement was both sustained and transformed, surviving mostly at the grassroots, within smaller women's organizations, and integrated into personal and political lives" (Chovanec, 2004, p. 206).

This idea of social movement continuity was affirmed in Chovanec's research in Chile. While most women of the second generation in Arica were no longer actively engaged in political parties or social movements in 2002, they maintained enduring ties of solidarity, commitment to a persistent set of beliefs and values, and socially relevant careers. None of these women had rejected the leftist orientation or social consciousness that developed in their families and/or through their social movement involvement. Consistent with findings from other studies (e.g., McAdam, 1989), these women typically actualized their social commitment in their work as:

- teachers or early childhood educators who hoped to have a positive influence on the upcoming generation.

- popular educators, counselors or social workers who worked with troubled youth and families, addicts, and abused women.

- community and feminist organizers and activists. 
- visual, text and performance artists who contribute educational messages and social critique through their artistic and cultural work.

It was also very common for this generation to talk about regrouping on a more personal level, within their homes and families, and within themselves as well. As one said, "I believe that what has to be done is to begin to change the person, to construct a different way of life." These mothers hoped to give their daughters a "solid foundation" of ideology, values, ethics, and habits from which to grow. And, despite all the challenges, misgivings, pain, and critique, all the women cherished the solidarity, collective action, and power in mutual commitment that marked the years of anti-dictatorship struggle.

The legacy of the elder (first) generation of women activists persists in spaces of

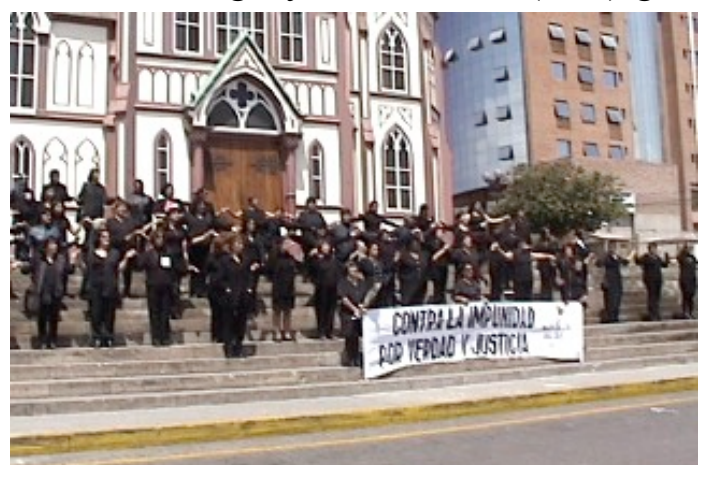

Mujeres de Luto 2006 in Arica, Chile participation that started in the $1980 \mathrm{~s}$, two of which have an ongoing presence in the community. First, Centro de Encuentro de la Mujer (CEDEMU) is a clear example of the endurance of a socialist-feminist praxis in Arica. A team of women from the first and second generations of activists maintain this small, marginally funded non-governmental organization. The main activities nowadays are a weekly radio show on women's issues and project work in the poorer

neighbourhoods. Second, Mujeres de Luto is an annual event where women stand in black and in silence on the steps of the cathedral for one hour on the anniversary of the coup (September 11). In recent years, this event has attracted more, younger women who attend with their mothers and grandmothers (H. González, personal communication, September 11, 2006). These small pockets of public activity have kept the movement from disappearing altogether.

Thus, the second generation exemplifies their previous commitments in new ways that have impact on younger generations, and the first generation nurtures two public spaces of activity and participation across generations. Movement continuity is thereby assured, albeit in modified and subdued forms, through these

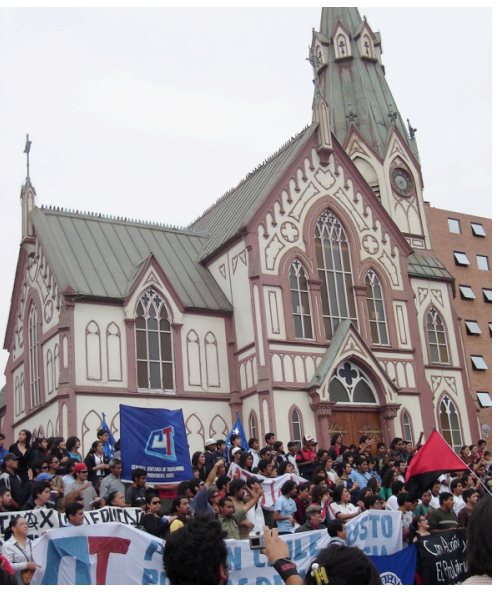

Revolución Pingüina 2006 in Arica, Chile intergenerational mechanisms.

\section{Implications for Education and Research}

Both themes considered above-critical social consciousness and social movement continuity - alert us to processes of learning across and between generations, that is, intergenerational learning. If we agree that significant intergenerational learning processes have been ignored, such as in the case of the lack attention to political education in the second generation, and that learning across generations occurs anyway 
because activists never completely shed their critical social consciousness and because mechanisms for social movement continuity, however subdued, exist, then, we argue, there is good reason to incorporate a deliberate educational dimension into social movement activism. As Freire (cited in Holst, 2002) reminds us, education and activism are in a dialectical relationship.

When we're in the process of mobilizing or organizing it begins to be seen also as an educational problem ... Education is before, is during and is afte r... It's impossible to organize without educating and being educated by the very process of organizing. (p. 80)

We propose that a means of accomplishing this educational imperative is through intentional political education by parents and by political parties. In an exploratory interview conducted recently with two student leaders in Arica, there is evidence of both in the current student movement.

\section{Parenting Education}

As uncovered here and elsewhere, parents are implicated in the early political socialization of the younger generations. A sixteen-year-old female student leader in Arica today shares how her family's material needs prompted an initial awareness of injustice and its relationship to education.

I am the daughter of a worker and my mother is a housewife. I realized that my father wasn't well paid and we had many needs ... I realized that one of the ways that I could help my family and many other families was through education. But first I had to recognize that our education is not very good, it isn't of good quality. I was also thinking that the way to reduce poverty, or to go forward, is through education. Therefore, so that this can be a way for everyone, it has to be good. So now I am fighting for a quality education that is equitable for everyone.

We contend that there is radical pedagogical potential in parenting, suggesting that a useful social role for radical adult educators is in parenting education.

Most parents are aware that they transmit basic values to their children; many may even intentionally educate their offspring in ethical and critical thinking. But how many are able to be radical educators of their children? How many would have the skills to initiate in their children the journey towards critical consciousness? Based on my findings, I suggest that parents are the "organic intellectuals" within family and community social systems and we, as adult educators, are challenged to find ways to work with parents in this important foundational work (Chovanec, 2004, p. 141).

\section{Political Parties}

Most of the women interviewed in Arica were members of political parties. Women in the first generation were expressly educated in the political ideologies of their parties. 
Second generation women decried the failure of their political party elders to provide the ideological education that contributes to the theoretical clarity and critical analysis needed for sustained social movement activism. Influenced first by her family's material circumstances, the young Penguins leader mentioned above then turned to a political party.

I began to look for a way to help in what was happening now, so I entered the Communist Party ... The Party influenced me in the sense that I entered there with a minimum of consciousness, but they showed me a little about the injustice and indignity of the world. So, they taught me a lot. And also, for my part, I have studied all that they taught me and I realized that there is often much inequality in the world and, because of this, you have to fight day by day and that, more than anything, that there is a time for the struggle and I am in that moment.

Political parties in Chile have considerable influence on the political education of citizens, including, as the example above indicates, on youth. Yet, in Canada, political parties are an undervalued and near-forgotten potential educational resource. Taking his cue from Gramsci (1971), Holst (2002) argues that it is the role of the political party to provide the educational leadership needed for the development of a critical consciousness. When political parties assume their role as political "schools," the party is in a position to "elaborate," as Gramsci says, the organic intellectual from within itself: "Organic intellectuals are not born but are formed through the educational activities of working-class parties" (Holst, 2002, p. 110). Revitalized for the current realities of transnational capital and purged of sexism and other oppressive apparatuses, political parties hold historical promise as institutions of radical adult education.

\section{Future Directions for Research}

As argued here, the informal learning of the younger generations of women through the legacy and teachings of mothers and grandmothers raises important research questions. In our work, we consider intergenerational learning between women in terms of the continuity of the women's movement and its implications for feminism(s). While we can see that young women are actively engaged in critical social analysis and action in the student movement, we do not yet know if they have any affinity to the kind of feminist analysis or praxis that mobilized their mothers and some of their grandmothers during earlier eras. These relationships require considerable research and are the focus of our ongoing work.

One might also consider other dynamics such as between mothers and sons, or more broadly across generations of activists of all genders. Equally important, and not addressed in this paper, is the informal learning of parents and grandparents from the youth, for example, sharing skills for the creative use of digital technologies in activist work. Ultimately, the recent emergence of the Penguin student activists on the political landscape in Chile uncovers exciting potential for further research on learning between generations that could inform social movements in any context. 


\section{Summary}

In this paper, we introduced an emerging social movement in Chile. The movement known as the Penguin Revolution is led by high school students using national strikes and school takeovers to protest the neo-liberalization of education initiated during the military dictatorship in the 1980s and sustained through almost two decades of a democratically elected centre-left government. The student movement came as a surprise to many because of the marked decline in political mobilization witnessed in the aftermath of the dictatorship. Against a vibrant history of protest and struggle that was sustained even through the brutal repression of the dictatorship, cynicism and disillusionment marked the transition years. Mothers and grandmothers, who carry the legacy of participation and leadership in feminist and anti-dictatorship struggle, retreated from formal politics and grassroots movements. Yet, their adolescent daughters are at the forefront of a new emergence of political activism. We propose that findings from an earlier study of the women's movement in Arica, Chile bear important clues to understanding the reemergence of social action in the current generation.

First, a strong critical social consciousness persists in the first and second generation of women despite various challenges. Having first acquired a critical social consciousness through the political socialization within their families and communities, it was brought to a level of engagement and integration through their committed social activism prior to and during the military regime.

A second and related theme is that, despite a general withdrawal from formal politics and grassroots movements, the women's enduring critical social consciousness reveals itself in the processes for social movement continuity that are evident in Arica. Second generation women actualize their social commitment in their personal development, in the ethics they transmit through parenting, and through their professional careers as change agents. For almost 25 years, first generation women have maintained two public mechanisms for social movement continuity in Arica-a struggling feminist NGO and an annual public demonstration - that keep the women's movement minimally alive across the three generations of women, even during this quiescent time.

Even informal learning, such as in the themes addressed here, is catalyzed more effectively if intentionally nurtured across generations. We propose that social movements deliberately incorporate an educational dimension that would cultivate intergenerational learning. Parents and political parties both hold remarkable potential for the kind of political socialization and education needed to revitalize and mobilize social movements over time.

Note: We wish to acknowledge the very supportive and ongoing research collaboration with Héctor M. González in Chile as wall as the helpful feedback provided on drafts of this paper by our colleague, Dr. Elizabeth Lange, and from an anonymous reviewer. We are also grateful for the financial assistance of a Roger S. Smith Undergraduate Research Award and a Killam Research Fund Operating Grant. 


\section{References}

Alarcón Ferrari, C. (2007). The student movement in Chile during 2006 and beyond: Reclaiming the right to education in a worldwide symbol of free market, neoliberalism and capitalist hegemony. Proceedings of the 5th Critical Management Studies Conference, University of Manchester, Manchester, UK.

Allman, P. (2001). Critical education against global capitalism. Westport, CT: Bergin \& Garvey.

Alvarez, S.E. (1999). Advocating feminism: The Latin American feminist NGO 'boom'. International Feminist Journal of Politics, 1(2), 181-209.

Baumgardner, J. \& Richards, A. (2000). Manifesta: Young women, feminism, and the future. New York: Farrar, Straus, and Giroux.

Bloque Social. (2006). La crisis educativa en Chile: Propuesta al debate ciudadano. Santiago, Chile: Author.

Bresnahan, R. (2003). Introduction: Chile since 1990: The contradictions of neoliberal democratization. Latin American Perspectives, 30(5), 3-15.

Centro de Estudios Nacionales de Desarrollo Alternativo (CENDA). (2007, April 11). Declaración publica: Nueva Ley General de Educación. Santiago, Chile: Author.

Chávez, G. (2006). Movimiento estudiantil chileno: "Hay fuertes sanciones hacia los jóvenes". Retrieved July 16, 2007, from

http://www.rebelion.org/noticia.php?id=41777

Chavkin, S. (1985). Storm over Chile: The Junta under siege. Westport, CT: Lawrence Hill and Company.

Chovanec, D.M. (2004). Between hope and despair: Social and political learning in the women's movement in Chile. Unpublished doctoral thesis, University of Alberta, Edmonton, AB.

Chovanec, D.M. (2006a). Between finding ourselves and losing ourselves: The consequences of social movement participation. Proceedings of the Annual Conference of the Canadian Association for the Study of Adult Education, York University, Toronto.

Chovanec, D.M. (2006b). Between hope and despair: Social and political learning in the women's movement in Chile. Proceedings of the Annual Conference of the Canadian Association for the Study of Adult Education, York University, Toronto.

Cortez Díaz, A. \& Villagra Parra, M. (1999). Imaginario y prácticas socio-políticas de las mujeres opositoras a la Dictadura Militar en Chile. Unpublished manuscript, Arica, Chile.

Craske, N. (1998). Remasculinisation and the neoliberal state in Latin America. In V. Randall \& G. Waylen (Eds.), Gender, politics and the state (pp. 100-120). London: Routledge.

della Porta, D. (1992). Introduction: On individual motivations in underground political organizations. International Social Movement Research, 4, 3-28.

Díaz Miranda, J. (2006). Cronología de la movilización de los estudiantes de secundaria Chile 2006 (No. 19). Buenos Aires: Foro Latinoamericano de Poíticas Educativas (FLAPE). 
Franceschet, S. (2001). Women in politics in post-transitional democracies: The Chilean case. International Feminist Journal of Politics, 3(2), 207-236.

Freire, P. (1990/1973). Pedagogy of the oppressed (Myra Bergman Ramos, Trans.). New York: Continuum.

Gamboa C.A., \& Pincheira T., I. (2006). Consideraciones para un diálogo entre pingünos y un elefante blanco. In LOM Ediciones (Ed.), Me gustan los estudiantes (pp. 2757). Santiago, Chile: Editor.

Gramsci, A. (1971). Selections from the prison notebooks (Quinton Hoare \& Geoffrey Nowell Smith, Trans.). New York: International Publishers.

Hatfield, T. (2006). Chile's student protests and the democratization of a semi-democratic society [Electronic Version]. Council on Hemispheric Affairs Press Release. Retrieved October 10, 2006 from http://www.coha.org/2006/07/06/chile'sstudent-protests-and-the-democratization-of-a-semi-democratic-society/.

Hipsher, P.L. (1996). Democratization and the decline of urban social movements in Chile and Spain. Comparative Politics, 28(3), 273-297.

Holst, J.D. (2002). Social movements, civil society, and radical adult education. Westport, CT: Bergin \& Garvey.

Hoogland, R.C., de Vries, P., \& van der Tuin, I. (2004). Feminist theory in intergenertatiional perspective. European Journal of Women's Studies, 11(4), 461472.

Internationalist Striker. (2006, June 13). March of the penguins Chile students arise. Retrieved March 28, 2007, from http://www.melbourne.indymedia.org/news/2006/06/114659.php

Klandermans, B. (1997). The social psychology of protest. Cambridge, MA: Blackwell.

Marwell, G., Demerath III, N.J., \& Aiken, M.T. (1993). 1960s civil rights activists turn forty: A generational unit at mid-life. In Philo C. Wasburn (Ed.), Research in political sociology (Vol. 6, pp. 175-195). Greenwich, CT: JAI Press.

Marx, G.T. \& McAdam, D. (1994). Collective behavior and social movements: Process and structure. Englewood Cliffs, NJ: Prentice Hall.

Matear, A. (2007). Equity in education in Chile: The tensions between policy and practice. International Journal of Educational Development, 27, 101-113.

McAdam, D. (1989). The biographical consequences of activism. American Sociological Review, 54, 744-760.

Moyano, M.J. (1992). Going underground in Argentina: A look at the founders of a guerilla movement. International Social Movement Research, 4, 105-129.

Observatorio Chileno de Políticas Educativas (OPECH). (2006, July 1). ¿Por qué hay que cambiar la LOCE y revisar la municipalización? Santiago, Chile: Author.

Olavarría, M. (2003). Protected neoliberalism: Perverse institutionalization and the crisis of representation in postdictatorship Chile. Latin American Perspectives, 30(6), 10-38.

Pinochet's Chile. (2000). Retrieved July 15, 2004, from http://www.washingtonpost.com/wp-srv/inatl/longterm/pinochet/overview.htm

Purvis, J. (2004). Grrrls and women together in the Third Wave: Embracing the challenges of intergenerational feminism(s). NWSA Journal, 16(3), 93-123.

Roberts, J. (2007, November 13). Chile education reform agreement signed. The Santiago Times. 
Schild, V. (1998). New subjects of rights? Women's movements and the consruction of citizenship in the "new democracies". In Sonia E. Alvarez, Evelina Dagnino , \& Arturo Escobar (Eds.), Cultures of politics, politics of cultures: Re-visioning Latin American social movements (pp. 93-117). Boulder, CO: Westview Press.

Schuurman, F.J. (1993). Modernity, post-modernity and the new social movements. In Frans J. Schuurman (Ed.), Beyond the impasse: New directions in development theory (pp. 187-206). London: Zed Books.

Setterfield, C. (2006, October 19). Santiago: 316 arrested in student strike effort. Santiago Times, p. 2.

Silva, E. (1991). The political economy of Chile's regime transition: From radical to "pragmatic" neo-liberal policies. In Paul W. Drake \& Iván Jaksic (Eds.), The struggle for democracy in Chile, 1982-1990 (pp. 98-127). Lincoln, NB: University of Nebraska Press.

Taylor, V. (1989). Social movement continuity: The women's movement in abeyance. American Sociological Review, 54(October), 761-775.

Van Dyke, N., McAdam, D., \& Wilhelm, B. (2000). Gendered outcomes: Gender differences in the biographical consequences of activism. Mobilization: An International Journal, 5(2), 161-177.

Vogler, J. (2006, June 21). Chile: The rise of the penguin revolution [Electronic Version]. Upside Down World. Retrieved October 27, 2007 from http://upsidedownworld.org/main/content/view/330/1/.

Whittier, N. (1995). Feminist generations: The persistence of the radical women's movement. Philadelphia, PA: Temple University Press.

\section{Photo References}

Mujeres de Luto 2006 in Arica, Chile. From private collection.

Los estudiantes. Retrieved February 12, 2008 from

http://www.flickr.com/photos/exrorro/162070268/in/pool-paroestudiantil2006/

Biblioteca. Retrieved February 12, 2008 from

http://www.flickr.com/photos/histerica_sweet/158454828/in/pool-paroestudiantil2006/

Women protesting in Arica, Chile during dictatorship. From private collection. 